\title{
AVAILABILITY OF RADIOCASIUM IN PLANT FROM SOIL: FACTS, MECHANISMS AND MODELLING
}

N.V. GONCHAROVA

\author{
International Sakharov Environmental University, \\ 23 Dolgobrodskaja str, \\ 220070 Minsk, Belarus
}

Received: $16 / 10 / 08$

Accepted: 10/03/09 *to whom all correspondence should be addressed: e-mail: goncharova@iseu.by

\begin{abstract}
Radiocaesium is an isotope that can enter the food chain after having been absorbed by plants from soil. Our ability to predict the consequences of an accidental release of ${ }^{137} \mathrm{Cs}$ depends mainly on the level of understanding of the mechanisms involved in ${ }^{137} \mathrm{Cs}$ interactions with different components of agricultural and natural ecosystems and their formalization into predictive models. In this study the impact of some environmental and physiological factors, such as root density and presence of AM (Arbuscular mycorrhizal) fungal hyphae, on the ability of plants to uptake and accumulate radiocaesium through the roots was investigated. Three plant species were used: pea, soybean and oats. Experimental data suggested that, as roots explore new volumes of soil during growth, the plant will continue to accumulate this radionuclide at high rates in the early stages of ontogenesis. If plants are established on a contaminated site they may not be able to remove all of this radionuclide from soil, especially if a substantial amount of the radionuclide has been leached below the root zone which is commonly $30-40 \mathrm{~cm}$ in depth. Laboratory experiments indicate that certain plants may be able to remove radionuclides, especially ${ }^{137} \mathrm{Cs}$, from soil over a time period of 5-20 years.
\end{abstract}

KEYWORDS: Radionuclide, Radiocaesium, Modelling, Fungal hyphae, Root system, Mycorrhizal.

\section{INTRODUCTION}

Radionuclides are distributed to soil and plants in the contaminated area by physically and biologically mediated nutrient cycling processes (Avery, 1996). Radionuclides, especially ${ }^{137} \mathrm{Cs}$, can accumulate as they move up the food chain (Church et al., 1990).

Remediation of soil contaminated with radionuclides using present technologies may require that soil be transported from the contaminated site and treated with various dispersing and chelating chemicals. Transport of soil requires heavy equipment, is time consuming and expensive; it may also result in additional dispersal of pollutants through possible spills. Therefore, few attempts have been made to remediate land contaminated with radionuclides. Mycorrhizae are symbiotic relationships between a soil fungus and host plant root. The plant provides the fungus with carbon in the form of sugars, and the fungus provides the plant with a mechanism that greatly enhances the ability of its root system to acquire nutrients and water. Plants inoculated with a specific mycorrhizal fungus have been shown to increase their ability to acquire necessary nutrients while removing large quantities of ${ }^{137} \mathrm{Cs}$ from soil (Varskog et al., 1994).

However, mycorrhizae responsiveness is determined not only by plant and fungal characteristics, but also by the characteristics of the soil on which the experiments are conducted.

We tested the influence of Arbuscular mycorrhizal inoculation on roots of three main agricultural species: pea, soybean and oats. These species exhibit differences in their root 
systems: soybean and pea (Fabaceae) have a "core-type" root system and oats (Graminaceae) has a fibrous root system.

These plants were grown in a soil collected in South Belarus, in the area contaminated by radionuclides. A control group was grown in soil of the same type but not contaminated.

The aim of this study was to assess the relation between availability of radionuclides in soil, mycorrhizal abundance and accumulation of radionuclides in plants.

\section{EXPERIMENTAL SETUP}

\subsection{Materials}

Soils of type Podzoluvisol were collected from uncontaminated and contaminated sites (0-30 $\mathrm{cm}$ horizon) from "Sudkovo" farm, Khoiniki district, Gomel region, Belarus. The specific activity of ${ }^{137} \mathrm{Cs}$ in the soil was $1983 \mathrm{~Bq} \mathrm{~kg}{ }^{-1}$. Resident mycorrhizae in both samples were killed by steam pasteurization at $121^{\circ} \mathrm{C}$ for $24 \mathrm{~h}$. Steam sterilization at $121^{\circ} \mathrm{C}$ is known to kill resident mycorrhizal spores, but does not change the soils organic structure or chemistry (Entry et al., 2002).

The entire experiment was replicated 3 times for each species.

\subsection{Chemical analysis of soils and Mycorrhizal inoculum preparation}

Soil moisture was determined gravimetrically after drying to a constant weight at $104^{\circ} \mathrm{C}$ for 24h. Bulk density was determined by the core method (Blake, 1965).

Soil $\mathrm{pH}$ was determined with a 1:1 pastier of soil and water (McLean, 1982).

Mycorrhizal soils containing Glomus mosseae and Glomus intraradices spores were obtained from the Collection of Arbuscular Mycorrhizal Fungi, Belorussian Research Institute for Soil Science and Agrochemistry. Arbuscular mycorrhizal fungi inoculums for soil with radionuclide (a non-mycorrhizal soil with radionuclide was used as control) were prepared using the procedure described by Entry et al. (1999).

\subsection{Mycorrhizal infection}

The roots of each test plant were removed by sieving the soil in each pot through a $0.5 \mathrm{~mm}$ opening. Three roots were collected, washed three times with distilled water and cut into pieces of approximately $3.0 \mathrm{~cm}$ lengths. Roots were cleaned by placing them in $10 \% \mathrm{KOH}$ solution. The solution and roots were placed in a microwave oven for $5 \mathrm{~min}$ and then placed $24 \mathrm{~h}$ in a solution of $0.05 \%$ trypan blue in lactoglycerol (Phillips and Hayman, 1970). The roots were inspected in a microscope with 100x magnification, and the percentage of root area infected was estimated using the line intersect technique described by Giovannetti and Mosse (1980).

\subsection{Plant growing conditions}

Plant seeds were immersed in $30 \% \mathrm{H}_{2} \mathrm{O}_{2}$ for 30 min to ensure the absence of pathogenic or mycorhizal fungi.

25 plants were sowed per pot; the pot surface was approx. $0.05 \mathrm{~m}^{2}$ and the quantity of soil was $5 \mathrm{~kg}$ per pot (dry soil).

Plants received $1.5 \mathrm{mg} \mathrm{N}$ as $\mathrm{NH}_{4} \mathrm{NO}_{3}$ and $\mathrm{KNO}_{3}, 0.5 \mathrm{mg} \mathrm{P}$ as $\mathrm{KH}_{2} \mathrm{PO}_{4}$ and $0.6 \mathrm{mg} \mathrm{K}$ as $\mathrm{KH}_{2} \mathrm{PO}_{4}$ and $\mathrm{KNO}_{3}$ in $10 \mathrm{ml} \mathrm{H}_{2} \mathrm{O}$ each week.

Plants were grown in the pot for 3 months in a greenhouse where the temperature was maintained at $22 \pm 3^{0} \mathrm{C}$. During that time, the seedlings were exposed to sunlight with photosynthetically active radiation of $240 \mu \mathrm{E} \mathrm{m}^{-2} \mathrm{~s}^{-1}$ and a photoperiod of $14-16 \mathrm{~h}$.

The entire experiment was replicated 3 times for each species.

\subsection{Sampling, measurement and calculations}

Hand shears were used to cut samples from the above-ground portion of the plants in each pot every 30 days during three month (April, May, and June). At the final harvest, the roots were also sampled. All roots were washed in water. All root and shoot tissue was dried at $80^{\circ} \mathrm{C}$ for $48 \mathrm{~h}$ and then weighed. 
Radioactivity of soil, plant and root samples was measured by gamma-spectrometry using a high purity $\mathrm{Ge}(\mathrm{Li})$ detector. Measurement times were extended until the counting error was reduced to less than $10 \%$.

The amount of ${ }^{137} \mathrm{Cs}$ removed was calculated by multiplying the $\mathrm{Bq}$ of radionuclide $\mathrm{g}^{-1}$ tissue by the total dry mass $(\mathrm{g})$ of the harvested tissue. The percentage of radiocaesium from the soil was determined by dividing the amount of radioisotope measured in seedling tissue by the amount of radiocaesium in each pot, multiplied by 100 .

The bioconcentration ratio or transfer factor (TF) was calculated as $\mathrm{Bq}$ radioisotope $\mathrm{kg}^{-1}$ in dry plant tissue / Bq radioisotope $\mathrm{kg}^{-1}$ dry soil.

Mass balances for each experiment were calculated using the formula given by Entry et al. (1999):

$M B=R_{a}-\left(R_{p s}+R_{p r}+R_{s}\right) \times 100$,

were

$\mathrm{MB}$ - mass balance or the percentage of ${ }^{137} \mathrm{Cs}$ accounted for,

$\mathrm{R}_{\mathrm{a}}$ - the activity $(\mathrm{Bq})$ of ${ }^{137} \mathrm{Cs}$ added to the soil,

$R_{p s}$ - the activity $(\mathrm{Bq})$ of ${ }^{137} \mathrm{Cs}$ accumulated over the course of the experiment in plant shoots,

$R_{p r}$ - the activity $(\mathrm{Bq})$ of ${ }^{137} \mathrm{Cs}$ accumulated over the course of the experiment plant roots and

$\mathrm{R}_{\mathrm{s}}$ - the amount of ${ }^{137} \mathrm{Cs}$ in the soil at the end of the experiment.

To evaluate plant mycorrhizal responsiveness we used formula given by Plenchette et al. (1983). They used the term "relative field mycorrhizal dependency" (RFMD).

According to Plenchette et al.

RFMD $=\frac{\text { (Dry weight of AM plant-Dry weight of non-AM plant }) \times 100}{\text { Dry weight of non-AM plant }}$

\subsection{Statistical methods}

Data were processed by two-way analysis of variance (ANOVA) and Fisher's protected least significant differences (LSD) when appropriate.

\section{RESULTS AND DISCUSSION}

The concept of the ${ }^{137} \mathrm{Cs}$ soil-plant pathway is shown in Figure 1 with its three parts: the soil solids (minerals, particulate organic matter), the soil solution and the plant. The exchange between the soil solids and the soil solution is the soil chemical reaction. The uptake of

${ }^{137} \mathrm{Cs}$ from the soil solution is controlled by plant physiology, i.e. the ion uptake process in the root cells and the transport to the above-ground parts. The ion uptake process has a particular role in the entire soil-plant transfer process. Several studies in solution culture have arrived at the conclusion that root uptake of ${ }^{137} \mathrm{Cs}$ is sharply reduced with increasing concentration of K (Goncharova, 2001). Caesium is not a nutrient but may be absorbed by the transport systems of its nutrient analogue $\mathrm{K}$. High concentrations of $\mathrm{K}^{+}$ions effectively reduce the chance that $\mathrm{a} \mathrm{Cs}^{+}$ion enters the plant through the $\mathrm{K}$ channels or carriers into the membranes of root cells. This leads to the conclusion that availability in plants of ${ }^{137} \mathrm{Cs}$ from soil is controlled by its mobility in soil and by the concentration of $\mathrm{K}$ in the soil solution.

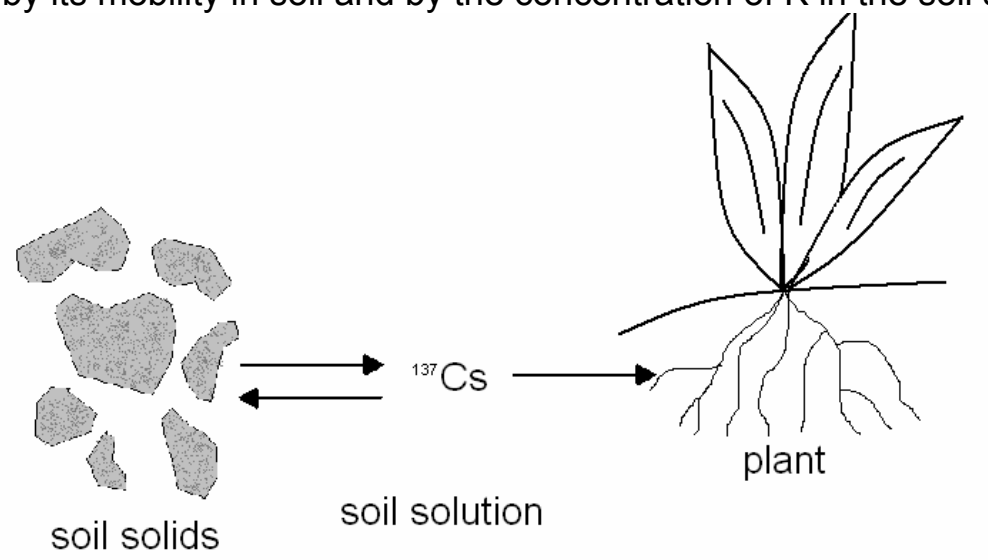

Figure 1. A conceptual presentation of the soil-plant transfer of ${ }^{137} \mathrm{Cs}$

The main chemical and physical characteristics of the soil used are presented in Table 1. 
Table 1. Chemical and physical parameters of the soil used

\begin{tabular}{|c|c|c|c|c|c|c|}
\hline $\begin{array}{l}\text { Hydroscopic } \\
\text { moisture, \% }\end{array}$ & pH & $\begin{array}{l}\text { Bulk density, } \\
\mathrm{g} \mathrm{cm}^{-3}\end{array}$ & $\begin{array}{c}\text { Organic } \\
\text { matter,\% }\end{array}$ & $\begin{array}{c}\text { Total C, } \\
\% \\
\end{array}$ & Clay, \% & $\begin{array}{c}\text { CEC, } \\
\text { meq } 100 g^{-1}\end{array}$ \\
\hline 0.6 & 6.9 & 2.8 & 2.0 & 1.7 & 10.0 & 7.9 \\
\hline
\end{tabular}

Many factors affect availability of radionuclides in plants. Soil $\mathrm{pH}$ has an important influence on their solubility (Bergeijk et al., 1992). For a more realistic description of the transfer of radionuclides from soil to plant material Gerzabek et al. (1998) introduced the calculation of "fluxes" using additional information like yield and growth time.

Another important factor affecting radionuclide availability is the CEC of soil, since the concentration of $\mathrm{Cs}^{+}$in solution is controlled by equilibrium phase partitioning between the aqueous and solid phases (Schuller et al., 1988). Although clay content is an inherent feature of soils, their organic matter content levels are directly influenced by agronomic factors such as tillage frequency (Sawhney, 1972).

Several experiments were carried out to determine whether two factors, soil organic mater content and mycorhizal infection, had a marked effect on plant accumulation (Drissner, 1998). $\mathrm{AM}$ fungi responded to $\mathrm{pH}$ in a highly variable fashion. The response of arbuscular mycorrhizal plants to $\mathrm{pH}$ has been studied for some very practical reasons, including potential negative effects of $\mathrm{H}^{+}$on plant productivity via direct effects on the endophyte and host physiology, and indirect effects via changes in soil processes, e.g. metal and base cation availability (Coughtrey et al., 1989; Clark et al., 1999). Some AM fungi did poorly in low-pH soils, while other fungi did poorly after acid-soils were limed (Mosse, 1972). It was found that the response of arbuscular mycorrhizas to soil $\mathrm{pH}$ seems to be dependent primarily on the fungal species (Sylvia et al.,1998). Some fungal species readily form arbuscular mycorrhizas in low-pH soils, while other species form mycorrhizas in higher pH soils (Entry et al., 2002).

The analysis of variance for several variables: plant biomass, concentration of ${ }^{137} \mathrm{Cs}$ in plant tissue, $\%$ accumulation by plant tissue, TF, above-ground biomass, root biomass and ${ }^{137} \mathrm{Cs}$ in soil indicated no significance $(p \leq 0.05)$.

The above-ground biomass of pea, soybeans, and oats removed in three harvests, contained from 4.5 to $23.4 \%$ of the total amount of the ${ }^{137} \mathrm{Cs}$ added to the soil (Table 2).

Table 2. ${ }^{137} \mathrm{Cs}$ accumulation by plant tissue not inoculated with AM (Bq)

\begin{tabular}{cccc}
\hline Harvests & $\begin{array}{c}\text { Pea } \\
\mathbf{x 1 0 ^ { 4 }}\end{array}$ & $\begin{array}{c}\text { Oat } \\
\mathbf{x 1 0}^{4}\end{array}$ & $\begin{array}{c}\text { Soybeans } \\
\mathbf{x 1 0}^{4}\end{array}$ \\
\hline 4 weeks & $2.4 \pm 0.2$ & $2.6 \pm 0.3$ & $2.2 \pm 0.5$ \\
\hline 8 weeks & $2.8 \pm 0.4$ & $3.9 \pm 0.6$ & $4.6 \pm 0.6$ \\
\hline 16 weeks & $3.4 \pm 0.4$ & $4.6 \pm 0.7$ & $6.2 \pm 0.8$ \\
\hline
\end{tabular}

When plants were inoculated with $\mathrm{AM}$, above-ground plant biomass, concentration of ${ }^{137} \mathrm{Cs}$, above-ground plant biomass, concentration of ${ }^{137} \mathrm{Cs}$ in plant tissue, \% accumulation of ${ }^{137} \mathrm{Cs}$ from soil and the TF in all three harvests increased compared to plants growing in the control soil (not inoculated with AM). Above-ground plant biomass, concentration of ${ }^{137} \mathrm{Cs}$ in plant tissue and \% accumulation of ${ }^{137} \mathrm{Cs}$ from soil increased in all three harvests in the plants with the highest sowing densities (Table 3).

Table 3. ${ }^{137} \mathrm{Cs}$ accumulation by plant tissue inoculated with $\mathrm{AM}(\mathrm{Bq})$

\begin{tabular}{cccc}
\hline Harvests & $\begin{array}{c}\text { Pea } \\
\mathbf{x} \mathbf{1 0}^{4}\end{array}$ & $\begin{array}{c}\text { Oat } \\
\mathbf{x 1 0 ^ { 4 }}\end{array}$ & $\begin{array}{c}\text { Soybeans } \\
\mathbf{x} \mathbf{1 0}^{4}\end{array}$ \\
\hline 4 weeks & $4.2 \pm 0.3$ & $6.4 \pm 0.2$ & $6.5 \pm 0.2$ \\
\hline 8 weeks & $5.6 \pm 0.2$ & $12.7 \pm 0.3$ & $8.2 \pm 0.2$ \\
\hline 16 weeks & $7.8 \pm 02$ & $17.3 \pm 0.2$ & $13.1 \pm 01$ \\
\hline
\end{tabular}


The concentration of ${ }^{137} \mathrm{Cs}$ in plant tissues in this study is comparable with results from the other studies. However, the proportion of ${ }^{137} \mathrm{Cs}$ removed from the soil by these plants is substantially higher than in experiment in the field (Goncharova, 1999; Krouglov et al., 1997). It is suggested that these plants extracted a high percentage of ${ }^{137} \mathrm{Cs}$ from the soil because:

a) root density was rather high;

b) plants grew rapidly, because growing conditions for these plant species were good, thus uptake of water and soil minerals was high;

c) root colonization by mycorrhizal fungi was high.

Inoculation of pea, soybean and oats with AM increased above-ground plant biomass, concentration of ${ }^{137} \mathrm{Cs}$ in plant tissue and the accumulation of ${ }^{137} \mathrm{Cs}$ from soil. Inoculation with AM increased root biomass, which resulted in greater quantities of ${ }^{137} \mathrm{Cs}$ from the soil. This data is comparable with our previous data (Goncharova et al., 2002).

In a modelling study based on data from experimental results, Kirk and Staunton (1989) found that the higher the density of roots in the soil the more ${ }^{137} \mathrm{Cs}$ was accumulated by a wide variety of grassland plants.

Although the ability to accumulate radionuclides varies among a wide array of plant species occupying different habitats, many plants growing on contaminated soils have been shown to accumulate radionuclides (Pinder et al., 1984; Murphy and Johnson, 1993). Laboratory experiments indicate that certain plants may be able to remove radionuclides, especially ${ }^{137} \mathrm{Cs}$, from soil over a time period of 5-20 years (Entry et al., 1999). Several researchers have documented the accumulation of ${ }^{137} \mathrm{Cs}$ in grasses and other herbaceous plants in the field (Nifontova et al., 1989; Whicher et al., 1990).

\section{CONCLUSIONS}

The objective of the above studu was to document ${ }^{137} \mathrm{Cs}$ uptake by plants in relation to contamination of grazing animals and incorporation of radionuclides into the food chain and not phytoremediation. In order to make phytoremediation of radionuclides or other elements that are considered pollutants practical, one must maximize root density, plant growing conditions and availability of the contaminant to the plant. Even though a majority of plants growing in soils contaminated with ${ }^{137} \mathrm{Cs}$ are able to accumulate these radionuclides, not all plants are able to maximize accumulation when put in cultivation. To adequately test the feasibility of phytoremediation, experiments with soil contaminated with ${ }^{137} \mathrm{Cs}$ must be made in the field. The relationships between time (harvests) and uptake of ${ }^{137} \mathrm{Cs}$ indicate that the rate of radionuclide accumulation by plants is most rapid during the flowering period (Goncharova et al., 1996; Goncharova 2001).

The amounts of ${ }^{137} \mathrm{Cs}$ removed from the soil are most likely due to the fast growth rates and the rapidly growing root system of plants during the initial stages of plant establishment. In the early stages of ontogenesis, plants grow rapidly and increase photosynthetic suffuses leaves area Root production will follow an exponential growth rate for weight and volume with respect to time (Van den Driessche, 1987). Our data suggest that as roots explore new volumes of soil during growth, the plant will continue to accumulate these radionuclides at high rates in the early stages of ontogenesis. If plants are established on a contaminated site they may not be able to remove all of these radionuclides from the soil, especially if a substantial amount of the radionuclide has been leached below the root zone which is commonly 30-40 cm in depth (Arapis et al., 1997; 1999).

The substantial increase in ${ }^{137} \mathrm{Cs}$ in plants inoculated with $\mathrm{AM}$ indicates that mycorrhizal inoculation in the field may improve uptake of ${ }^{137} \mathrm{Cs}$ by plants in contaminated soils. When inoculated with AM the plant species tested removed as much as $67.5 \%$ of the ${ }^{137} \mathrm{Cs}$ added to the soil. The extent of AM infection in a plant will vary widely depending on concentration of viable spores in the soil, plant species and environmental factors that affect plant growth (Sylvia and Williams, 1992). AM are ubiquitous, and most species do not have specific host preferences. In soil with established angiosperms, the addition of spores to the soil may not increase host colonization. If the contaminated soil is disturbed and is void of plants, addition of mycorrhizal fungi spores may increase mycorrhizal colonization of plants and enhance plant survival and uptake of water, nutrients and radionuclides. The effects of inoculation with AM on ${ }^{137} \mathrm{Cs}$ uptake by plant species have been investigated primarily in greenhouses, where environmental and soil conditions could be easily controlled. They have not been studied in 
detail in the field. A series of studies that investigates the effects of soil compaction on AM formation and function on several plant species and across a range of soil types would be a valuable contribution to the literature.

\section{ACKNOWLEDGEMENTS}

This work was supported through DAAD and NATO Fellowships grants. The participation in the PRE9 conference was supported by the TEMPUS project JEP-27177-2006(BY).

\section{REFERENCES}

Arapis G., Cheshakov A., Ivanova T., Potapov V. and Sokolik G. (1999) Evalution of dose equivalent rate reduction as a function of vertical migration of ${ }^{137} \mathrm{Cs}$ in contaminated soils, $\mathrm{J}$. Environ.Radioactivity, 46, 251-263.

Arapis G., Petrayev E., Shagalova E., Zhukova O., Sokolik G. and Ivanova T. (1997) Effective migration velocity of ${ }^{137} \mathrm{Cs}$ and ${ }^{90} \mathrm{Sr}$ as function of the type of soils in Belarus, $J$. Environ.Radioactivity, 34, 171-185.

Avery S.V. (1996) Fate of caesium in the environment: distribution between the abiotic and biotic components of aquatic and terrestrial ecosystems, J. Environ. Radioactivity, 30(2), 139-171.

Bergeijk K.E., Noordijk H. and Lembrechts J. (1992) Influence of pH, soil type and soil organic matter content on soil to plant transfer of radioceasium and strontium as analyzed by non parametric method, J. Environ. Radioactivity, 15, 265-276.

Blake G.R. (1965) Bulk density. In: Methods of Soil Analysis. Part1, Black C.A. et al.(eds), ASA, Madison, WI, Agron. Monog., 9, 374-390.

Church B.W., Wheeler D.L., Campbell C.M., Nutley R.V. and Ansphaugh L.R. (1990) Overview of the Department of Energy's Off-site Radiation Exposure Review Project (ORERP), Health Physics, 59, 503-510.

Clark C.A., Zeto S.K. and Zobel R.W. (1999) Arbuscular mycorrhizal fungal isolate effectiveness on growth and root colonization of Panicum virgatum in acidic soil, Soil. Biol. Biochem., 31, 1757-1763.

Coughtrey P.J., Kirton J.A. and Mitchell N.G. (1989) Transfer of radioactive caesium from soil to vegetation and comparison with potassium in upland grasslands, Environmental Pollution, 62, 281-315.

Drissner J., Burmann W., Enslin F., Heider R., Klemt E., Miller R. et al. (1998). Availability of casium radionuclides to plants - classification of soil and role of mycorrhiza, $\mathrm{J}$. Environmental Radioactivity, 41, 19-32.

Entry J.A., Rygiewicz P.T., Watrud L.S. and Donnelly P.K. (2002) Influence of adverse soil conditions on the formation and function of Aruscular mycorrhizas, Advances in Environmental Research, 7, 123-138.

Entry J.A., Watrud L.S. and Reevers M. (1999) Accumulation of ${ }^{137} \mathrm{Cs}$ and ${ }^{90} \mathrm{Sr}$ from contaminated soil by three grass species inoculated with mycorrhizal fungi, Environmental Pollution, 104, 449-457.

Gerzabek M.H., Strebl F. and Temmel B. (1998) Plant uptake of radionuclides in lysimeter experiments, Environmental Pollution, 99 (1), 93-103.

Giovannetti M. and Mosse B. (1980) An evaluation technique for measuring vesicular arbuscular mycorrhizae infection in roots, New Phytologist, 84, 489-500.

Goncharova N.V. (2001) The transport of ${ }^{137} \mathrm{Cs}$ and ${ }^{90} \mathrm{Sr}$ across root cell membranes. Revue de Cytologie et Biologie vegetales, Le Botaniste, 25(1/2), 15-20.

Goncharova N.V. (1999) Influence of elevated chronic radionuclide contamination on plants, Revue de Cytologie et Biologue vegetales-Le Botaniste, 23 (3/4), 11-18

Goncharova N., Arapis G. and Lopareva E. ( 2002) Regulation of radiopollutant uptake in the soil-plant system, Revue de Cytologie et de Biologie Vegetales Le Botaniste, 26(1/2), 21-25.

Goncharova N., Davydenko O., Zhebrakova I. and Russkikh I. (1996) Manifestation of genotypic diversity of soya varieties grown in the zone subjected from the Chernobyl Nuclear Power Plant, Journal Plant Physiol and Biochemistry, Spesial issue, 224.

Kirk G.J.D. and Staunton S. (1989) On predicting the fate of radioactive cesium in soil beneath grassland, Journal of Soil Science, 40, 71-84.

Krouglov S.V., Filipas A.S., Alexakhin R.M. and Arkhipov,N.P. (1997) Long-term study on the transfer of ${ }^{137} \mathrm{Cs}$ and ${ }^{90} \mathrm{Sr}$ from Chernobyl-contaminated soils to grain crops, $J$. 
Environmental Radioactivity, 34 (3), 267-343.

McLean R.L. (1982) Soil pH and lime requirement. In: Methods of Soil Analysis. Part 2. Chemical and Microbiological Properties, Page A.L., Miller R.H. and Keeney D.R. (Eds.), American Society of Agronomy, Madison, WI.

Mosse B. (1972) Effects of different Endogone strains on the growth of Paspalum notatum, Nature, 229, 221-223.

Murphy, C.E. and Johnson T.L. (1993) Vegetative uptake of technetium-99 from buried, solidified, low level radioactive waste, Journal of Environmental Quality, 22,793-799.

Nelson D.W. and Sommers L.E. (1982) Total carbon, organic carbon and organic matter. In: Methods of Soil Analysis. Part 2. Chemical and Microbiological Properties, Page A.L., Miller R.H. and Keeney D.R. (Eds.), American Society of Agronomy, Madison, WI.

Nifontova M.G., Kulikov G., Tarshis G.I. and D'yachenko D. (1989) Radioecological study of natural ecosystems in vicinity of atomic power stations, Ekologia, 3, 40-45.

Phillips J.M. and Hayman D.S. (1970) Improved procedures for clearing roots and staining parasitic and vesicular arbuscular mycorrhizal fungi for rapid assessment of infection, Transactions of the British Mycolögical Society, 55, 158-160.

Pinder III J.E., McLeod K.W., Alberts J.J., Adriano D.C. and Correy J.C. (1984) Uptake of ${ }^{244} \mathrm{Cm}$ and ${ }^{238} \mathrm{Pu}$ and other radionuclides by trees inhabitating a contaminated floodplain, Health Physics, 47, 375-384.

Plenchette C., Fortin J.A. and Furlan V. (1983) Growth responses of several plant species to mycorrhizae in soil of moderate P fertility, Plant Soil, 70, 199-209.

Rhoades J.D. (1982) Cation exchange capacity. In: Methods of Soil Analysis. Part 2. Chemical and Microbiological Properties, Page A.L., Miller R.H. and Keeney D.R. (Eds.), $2^{\text {nd }}$ Edition. ASA and SSSA, Madison, WI, Agron.Monogr., 9, 149-158.

Sawhney B.L (1972) Selective sorption and fixation of cations by clay minerals: A review, Clays and clay minerals, 20, 93-100.

Schuller P., Handl J. and Trumper R.E. (1988).Dependence of the ${ }^{137}$ Cs soil-to-plant transfer factor on soil parameters, Health Physics, 55, 575-577.

Sylvia D.M., Fuhrmann J.J., Hartel P.G. and Zuberer D.A. (1998) Principles and Applications of Soil Microbiology, Prentice Hall, Upper Saddle River, NJ.

Sylvia D.M. and Williams S.E. (1992) Vesicular-arbuscular mycorrhizae and environmental stress. In: Mycorrhizae in Sustainable Agriculture, Bethlenfalvay, G.J., Linderman, R.G (Eds.), American Society of Agronomy, Special Publication No.54,Madison, WI, USA.

Van den Driessche R. (1987) Importance of current photosynthate to new root growth in planted conifer seedlings, Canadian Journal of Forest Research, 17, 776-781.

Varskog P., Naeumann R. and Steinnes E. (1994) Mobility and plant availability of radioactive Cs in Natural soil in relation to stable Cs, other alkali elements and soil fertility, J. Environ. Radioactivity, 22, 43-53.

Whicher F.W., Pinder J.E., Alberts J.J. and Brisbin L.Jr. (1990) Distribution of radionuclides in an abandon reactor cooling reservoir, Ecological Monographs, 60, 471-496. 